\title{
Cost-benefit Analysis of Using Recycled Coarse Aggregate in Plain and Fibre Reinforced Concrete
}

\author{
Ganesh D. Awchat ${ }^{1 *}$, Madhav B. Kumthekar ${ }^{2}$ \\ 1 Department of Civil Engineering, Shri Guru Gobind Singhji Institute of Engineering \& Technology, Nanded - \\ 431606, Maharashtra, India \\ 2 Department of Civil Engineering, Government College of Engineering, Karad - 415124, Maharashtra, India \\ * Corresponding author's e-mail: gdawchat@gmail.com
}

\begin{abstract}
The tendency of demolition has increased to improve economic gains, functional and structural performance, and unloading expenses due to the inaccessibility of an appropriate site in a nearby area. As a result, effective utilisation of construction and demolition waste materials in the form of Recycled Coarse Aggregate of $20 \mathrm{~mm}$ $\& 10 \mathrm{~mm}$ is possible while conserving non-renewable natural resources. Even though recycled coarse aggregate (RCA) is a cost-effective material that provides solutions to solid waste management, it is also viewed as second-rate in terms of its basic properties compared to natural coarse aggregate (NCA). This study attempted to design two mix proportions for natural aggregate concrete (NAC) and recycled aggregate concrete (RAC). RAC was supplemented with Hooked Steel Fibres at a rate of $0 \%, 0.25 \%, 0.5 \%$, and $0.75 \%$ per cubic metre. Compressive strength was considered a benefit parameter, whereas the state schedule of rates (SSR), 2020-21, was used to estimate cost. The experimental results discovered that RAC with $0.25 \%$ steel fibres (SF) per cubic metre achieved 7.27\% lesser compressive strength results than NAC in Mix-1 of M25 grade, whereas it is 11.64\% lesser compared to NAC of Mix-2 of M40 grade at 28 days, respectively. This related decrease in compressive strength compared to NAC is within the acceptable limit of Indian Standards. At the same time, the cost analysis of RAC with $0.25 \%$ steel fibres per cubic metre showed $1.26 \%$ and $2.16 \%$ higher cost than NAC of M25 \& M 40 . It revealed that $0.25 \% \mathrm{SF}$ per cubic metre in RAC provides an economically viable solution in terms of cost and benefits compared to NAC of a similar mixture.
\end{abstract}

Keywords: natural aggregate concretes, recycled aggregate concretes, steel fibres, compressive strength, state schedule of rates.

\section{INTRODUCTION}

After World War II, when Europe was faced with urgent rebuilding needs, recycling waste materials, especially building rubble, into new concrete construction with good results was conducted on a large scale. Concrete creation and demolition wastage generation are the primary factors contributing to constant $\mathrm{CO}_{2}$ emission into the atmosphere [1]. Under the pressure of environmental protection agencies, the construction industries are turning towards demolished concrete as an aggregate for new concrete production, referred to as RAC [2]. The general development and destruction of waste generation in 40 nations reached more than 3.0 billion tons yearly until 2018, and this pattern is expanding continually. Discarded or demolished reinforced concrete structures, concrete pavements, precast concrete units etc., are the primary sources of RCA. With construction and demolition (C\&D) of building materials, a new aggregate is produced and utilised for green concrete production [3]. After the destruction of concrete elements, they are screened, i.e., foreign matters such as steel, wood hardware, plastics, lumber, dirt etc., are separated from the rubble. The rubble is then crushed and screened to obtain the required size of RCA. Even though reused aggregate instead of normal aggregate has 
now received extensive consideration as a reasonable strategy, its uses are restricted. A few specialists have rejected reused aggregate for structural development because of the absence of examination and the negative business perspectives [4].

Further investigation is expected to control reused aggregate to guarantee medium-strength basic of the reused aggregate concrete created [5]. Then again, a past examination has indicated that by adding SF in concrete, the properties of reused aggregate improved. Nonetheless, adding SF will bring about the additional cost that ought to be balanced by the benefits accomplished. One needs to find the balance between the accomplished structural properties and the extra expense. In order to overcome this issue, this examination was aimed at dissecting the cost adequacy of reused aggregate concrete and $\mathrm{SF}$ in its ideal mix to acquire the desired outcomes.

Thinking about the compressive strength at 7 and 28 days for the natural and reused aggregate concretes, it was found that the strength improvement with age for the two sorts of concrete is comparable. A portion of the reused aggregate concretes demonstrated an imperceptibly higher pace of strength improvement with age than natural concretes [6]. Recycled aggregate concrete has a lower compressive strength in the range of 5 to $10 \%$ than conventional concrete at the same water/cement ratio and equal workability. When the concrete fails, it was also observed that the adherent mortar on the recycled aggregate appeared to be the weakest link. The compressive strength of reused aggregate concrete is lower than that of parent concrete [7]. Reusing aggregate concrete requires a moderately lower water/concrete ratio compared to new concrete [8]. It was observed that at a high level of reused coarse aggregates $(50 \%, 100 \%)$, the addition in compressive strength of reused aggregate concrete ranged from 12 to $16 \%$ when the normal concrete strength expanded by $42 \%$ over the most recent 21 days of 28 days restoring period [9]. The mean compressive strength following 28 days was diminished 85 to $90 \%$ with $100 \%$ reused aggregates as a substitute for the coarse aggregate [10]. The compressive strength of RAC with SF, about $1 \%$ volume fraction, was lower than that of original concrete [11]. There was a reducing strength with increasing substitutions of reused aggregates in normal aggregates [12]. It was noticed that the compressive strengths of steel fibrous concrete in all the cases were slightly higher than no fibrous concrete. The outcomes demonstrated that the expansion of SF improved 28 days compressive strength, increasing 10 to $30 \%$ scopes with different water/concrete ratio, reused aggregate, fly ash, and SF volume part of $1.5 \% \mathrm{~m}^{3}$ concrete [13]. The compressive strength of reused aggregate can be $15 \%$ to $25 \%$ lower than that of the concrete made with virgin aggregates with reused SF aggregates to supplant the normal aggregate by $0 \%, 25 \%, 50 \%$ and $100 \%$ [14]. An inherent weakness in High Strength Concrete can be avoided by reinforcing the concrete with randomly oriented fibres [15]. A combination of RA and SF for beam was identified by several preliminary studies $[16$, 17]. In order to confirm this, more experiments and structural tests are necessary. In addition, despite the prediction of several environmental benefits with the use of RCA, the economic viability of this mixture with the addition of SF is unknown.

\section{OBJECTIVE OF RESEARCH}

The present work deals with RCA with SF to produce RAC concrete of M25 and M 30 grade. It was compared with conventional NAC of similar grade from a strength and economic profitability point of view. The following objectives were discussed in the current study:

- To investigate the appropriate dose of SF to be used in RAC to provide a viable solution as an alternative to conventional NAC from the compressive strength point of view.

- To identify the benefits and drawbacks of the integrated use of RCA and SF for concrete compressive strength, which used for reinforced concrete work.

- To assess the cost of RCA by conducting interviews of six major crushing plants in and around the Nanded district from various stages of aggregate production from stones or rocks.

- To work out a cost per cubic metre for the production of RCA with SF in the mixes of RAC concerning SSR, 2020-21 [18].

- Economic profitability analysis from strength and cost parameter for the use of RCA as cent percent replacement of NCA.

\section{RESEARCH METHOD}

The present study aimed at two main stages. The first stage aimed to conduct experiments by casting concrete cubes of M25 and M30 grade using NAC and replacing it with RCA cent percent with SF to evaluate compressive strength in a research 
laboratory climate using quantitative investigation. For the most part, three examination approaches found as quantitative, subjective and blended techniques were adopted to conduct a cost-benefit analysis (CBA) [19]. Since the present study expected to test concrete combinations and economic profitability, a quantitative methodology was used. The subsequent stage required acquiring cost information for the Cost Benefit Analysis (CBA). The second stage involved estimating the cost of RCA by interviewing six major crushing plants in and around the Nanded district from various stages of aggregate production from stones or rocks. Cost per cubic metre for the production of RCA with SF in the mixes of RAC concerning SSR, 2020-21 was considered as a parameter for assessment. CBA was carried out to provide statistical values of cost per cubic metre for production of RAC. It gives the customer or contractor a choice to opt for RAC with SF to replace NAC.

Table 1. Physical characteristics of sand

\begin{tabular}{|l|c|}
\hline \multicolumn{1}{|c|}{ Test } & Results \\
\hline Specific gravity & 2.621 \\
\hline Fineness modulus & 2.66 \\
\hline Water absorption & $1.2 \%$ \\
\hline Silt content & $1.2 \%$ \\
\hline
\end{tabular}

\section{Stage 1: Experiments}

Due to non-availability of mix design methodology using RCA, a mix design suggested by [20, 21] was first used to prepare NAC mixes i.e. NA \& NB having mix proportions [1:1.77:2.65:0.53] and [1:1.58:2.36:0.48], respectively. Afterwards, NA \& NB was $100 \%$ replaced by RCA to prepare plain mixes of RA \& RB with the same mix proportions confirming M25 \& M30 grade. The RA \& RB mixes were then supplemented by $0 \%, 0.25 \%, 0.5 \%$ and $0.75 \% \mathrm{SF}$ per $\mathrm{m}^{3}$ of concrete. At this stage, a two mix design with various mixture proportions was tried for compressive strength to decide the ideal combination equal to NAC. The NCA and RCA were utilised and introduced as Figure 1 is inside adequate particle size distribution scopes [22]. The water absorption rates of RCA are $4.5 \%$ and $3.6 \%$ for $10 \mathrm{~mm}$ and $20 \mathrm{~mm}$, individually, while the rates for NCA are $2.075 \%$ and $2.40 \%$ for $10 \mathrm{~mm}$ and $20 \mathrm{~mm}$, separately.

In the present work, fine aggregate used was locally available sand confirming BIS grading curve-II and presented in Table 1.

Ordinary Portland Cement (OPC) of 43 grade utilised in the entire study, which confirmed to [23]. The factors that are important in selecting a type of cement are compressive strength at various ages,

Table 2. Chemical properties of OPC 43 grade cement

\begin{tabular}{|l|c|c|}
\hline \multicolumn{1}{|c|}{ Chemicals available } & Results & Max. Permissible Limits [20] \\
\hline $\begin{array}{l}\left(\mathrm{CaO}-0.7 \mathrm{SiO}_{2}\right) \\
\left(2.8 \mathrm{SiO}_{2}+1.2 \mathrm{Al}_{2} \mathrm{O}_{3}+6.5 \mathrm{Fe}_{2} \mathrm{O}_{3}\right)\end{array}$ & 0.90 & 0.66 to 1.02 \\
\hline $\mathrm{Al}_{2} \mathrm{O}_{3} / \mathrm{Fe}_{2} \mathrm{O}_{3}(\%$ by mass $)$ & 1.34 & 0.66 Min. \\
\hline Insoluble Residue $\%$ by mass) & 1.68 & 3.0 Max. \\
\hline Magnesia (\% by mass) & 3.02 & 6.0 Max. \\
\hline Sulphuric Anhydride (\% by mass) & 1.67 & 3.0 Max. \\
\hline Total Loss on Ignition (\% by mass) & 1.74 & 5.0 Max. \\
\hline Total Chloride (\% by mass) & 0.01 & 0.10 Max. \\
\hline
\end{tabular}

a)

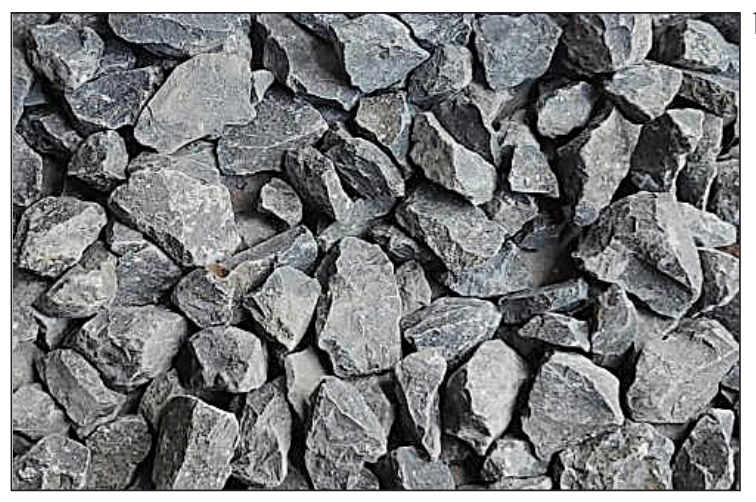

b)

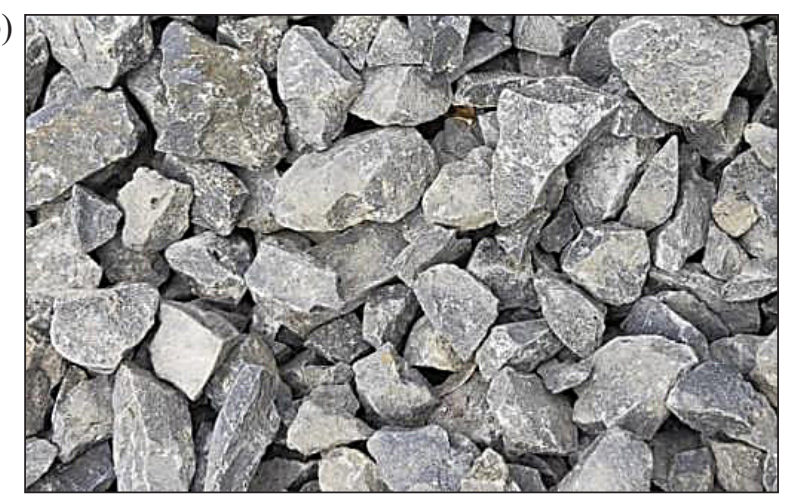

Fig. 1. Coarse Aggregate; a) Natural Aggregate; b) Recycled Aggregate 
Table 3. Physical properties of OPC 43 grade cement

\begin{tabular}{|l|c|c|}
\hline \multicolumn{1}{|c|}{ Type of property } & Results & Max. Permissible Limits [20] \\
\hline Fineness $\left(\mathrm{M}^{2} / \mathrm{Kg}\right)$ & 277.30 & $228 \mathrm{Min}$. \\
\hline Initial Setting Time & $215 \mathrm{Min}$ & $30 \mathrm{Min}$. Min. \\
Final Setting Time & $310 \mathrm{Min}$ & $600 \mathrm{Min}$. Max. \\
\hline Avg. Compressive strength & $47.9 \mathrm{MPa}$ & $33 \mathrm{MPa}$. Min. \\
7 days & $57.8 \mathrm{MPa}$ & $43 \mathrm{MPa}$. Min. \\
28 days & 1.00 & 10.0 Max. \\
\hline $\begin{array}{l}\text { Soundness Lee-chateliar } \\
\text { expansion (mm) }\end{array}$ & 3.14 & 3.15 \\
\hline Specific gravity & & 3 \\
\hline
\end{tabular}

Table 4. Chemical properties of water

\begin{tabular}{|l|c|c|}
\hline \multicolumn{1}{|c|}{ Parameter } & Results & Max. Permissible Limits [18] \\
\hline $\mathrm{pH}$ & 6.42 & $6.5-8.5$ \\
\hline Chlorides & $35 \mathrm{mg} / \mathrm{l}$ & $2000 \mathrm{mg} / \mathrm{l}$ \\
\hline Alkanity & $5 \mathrm{ml}$ & $25 \mathrm{ml}$ \\
\hline Sulphates & $128 \mathrm{mg} / \mathrm{l}$ & $400 \mathrm{mg} / \mathrm{l}$ \\
\hline Fluorides & $0.03 \mathrm{mg} / \mathrm{l}$ & $1.5 \mathrm{mg} / \mathrm{l}$ \\
\hline Organic Solids & $42 \mathrm{mg} / \mathrm{l}$ & $200 \mathrm{mg} / \mathrm{l}$ \\
\hline Inorganic Solids & $118 \mathrm{mg} / \mathrm{l}$ & $3000 \mathrm{mg} / \mathrm{l}$ \\
\hline
\end{tabular}

fineness, the heat of hydration, alkali content, the $\mathrm{C}_{3} \mathrm{~A}$ content. Test results of the physical properties of OPC are given in Table 2 and 3, respectively.

Potable tap water was tested in Environmental Engineering laboratory of the the Institute, used for casting specimens, and confirms to BIS:456-2000 [21]. Laboratory tests result presented in Table 4.

Crimped SF was made up of stainless steel thin wire in the form of hooked steel fibres confirming to A820, 2013 [24], and its characteristic are presented in Table 5.

The SF volume changed between $0.25 \%$, $0.5 \%$ and $0.75 \%$ per cubic metre while RCA replacement adopted is $100 \%$ with $20 \mathrm{~mm}$ as 60
Table 5. Physical properties of hooked SF

\begin{tabular}{|l|c|}
\hline \multicolumn{1}{|c|}{ Test } & Results \\
\hline Tensile strength & $1594.94 \mathrm{~N} / \mathrm{mm}^{2}$ \\
\hline Length & $30 \mathrm{~mm}$ \\
\hline Diameter & $0.6 \mathrm{~mm}$ \\
\hline Aspect ratio (length /diameter ratio) & 50 \\
\hline Density & $7800 \mathrm{~kg} / \mathrm{m}^{3}$ \\
\hline
\end{tabular}

$\%$ and $10 \mathrm{~mm}$ as $10 \%$, as displayed in Table 6 . In a concrete mixer, the quantity of aggregates poured and pre-soaking water was added first, before pouring SF and revolving it for 10 minutes so that RCA could absorb a sufficient quantity of

Table 6. Mix compositions with compressive strength results

\begin{tabular}{|c|c|c|c|c|c|c|c|c|c|c|}
\hline \multirow{3}{*}{$\begin{array}{l}\text { Mix } \\
\text { ID }\end{array}$} & OPC & Water & FA & NCA & & & \multirow{3}{*}{ SF (\%) } & \multicolumn{3}{|c|}{ Comp.Strength (MPa) } \\
\hline & \multirow{2}{*}{\multicolumn{4}{|c|}{$\left(\mathrm{kg} / \mathrm{m}^{3}\right)$}} & 20 & 10 & & 7 & 14 & 28 \\
\hline & & & & & & & & \multicolumn{3}{|c|}{ (Days) } \\
\hline NA & 361.5 & 191.6 & 640 & 958 & 0 & 0 & 0 & 21.78 & 23.85 & 36.35 \\
\hline RA & 361.5 & 191.6 & 640 & 0 & 575 & 383 & 0 & 16.98 & 18.36 & 27.26 \\
\hline RAF-1 & 361.5 & 191.6 & 640 & 0 & 575 & 383 & 0.25 & 18.29 & 20.74 & 33.80 \\
\hline RAF-2 & 361.5 & 191.6 & 640 & 0 & 575 & 383 & 0.5 & 19.38 & 22.18 & 34.90 \\
\hline RAF-3 & 361.5 & 191.6 & 640 & 0 & 575 & 383 & 0.75 & 18.73 & 21.47 & 34.35 \\
\hline NB & 399.1 & 191.6 & 630 & 942 & 0 & 0 & 0 & 23.41 & 29.48 & 39.00 \\
\hline RB & 399.1 & 191.6 & 630 & 0 & 565 & 377 & 0 & 18.26 & 22.11 & 28.08 \\
\hline RBF-1 & 399.1 & 191.6 & 630 & 0 & 565 & 377 & 0.25 & 19.43 & 25.35 & 34.71 \\
\hline RBF-2 & 399.1 & 191.6 & 630 & 0 & 565 & 377 & 0.5 & 20.36 & 26.53 & 36.27 \\
\hline RBF-3 & 399.1 & 191.6 & 630 & 0 & 565 & 377 & 0.75 & 19.89 & 25.94 & 35.49 \\
\hline
\end{tabular}


water. After that, sand, cement, and the required quantity of water and SF were thoroughly mixed in a container, and put in the concrete mixer and revolved for 4-5 minutes. SF of required quantity was added afterwards. Thoroughly mixed concrete was filled in cube mould in three equal layers \& kept over vibration table for uniformity. A total of 60 cubes $(150 \times 150 \times 150) \mathrm{mm}$ of M25 \& M30 concrete grade cubes were tested under the compression testing machine of 100 tonnes capacity for compressive strength measurement, as presented in Figure 2.

Figure 3 represents the relationship of compressive strength $\&$ concrete age for various concretes of mix-1. Compressive strength of RAF-1, RAF- 2 and RAF- 3 at 7 days is $17.42 \%, 11.66 \%$ \& $15.06 \%$ less than NA. This diminishing strength at 7 days demonstrates deficient air restoring of concrete at an early age with SF. RA exhibits $24.77 \%, 26.01 \%$ and $28.58 \%$ lesser compressive strength than NA of mix-1 at 7, 14 and 28 days, respectively. The reduction in strength is seen because of a poor bond between RCA and other constituents of concrete. The results show that there is a reduction in compressive strength of RAF-1, RAF-2 and RAF-3 when contrasted with NA by $13.94 \%, 7.25 \% \& 10.50 \%$ and $7.27 \%, 4.07 \%$ \& $5.66 \%$ at 14 and 28 days separately. The compressive strength of RA with different volume fraction of SF at an early age is relatively increasing due to the high absorption capacity of old mortar adhered to the rough texture of RCA and RCA. It provides improved bonding and interlocking characteristics between the mortar, RCA, and $\mathrm{SF}$ in agreement with the observations $[25,26]$. It was observed that the compressive strength at 28 days of RA for mix-1 increased along with the percentage of SF up to $0.5 \%$ per cubic metre. Beyond SF, $0.5 \%$ per cubic metre, a trend of increase in compressive strength declined.

Figure 4 shows a connection between compressive strength and concrete age for various concretes for mix-2. At 7 days, the compressive strengths of RBF-1, RBF-2 and RBF-3 were $18.58 \%, 13.94 \%$ \& $16.25 \%$ lesser, respectively, as compared to NB. This decrease in strength at 7 days demonstrates inadequate air relieving of RCA at an early age in SF. RB exhibits $24.71 \%$,

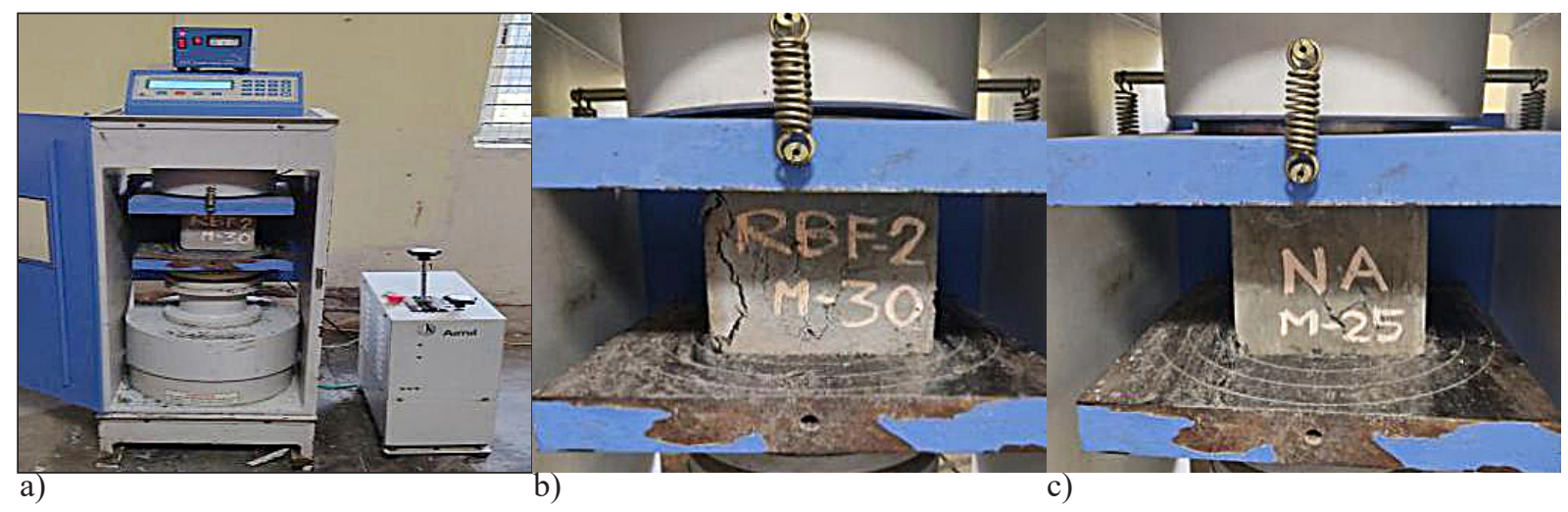

Fig. 2. Testing of cube specimens

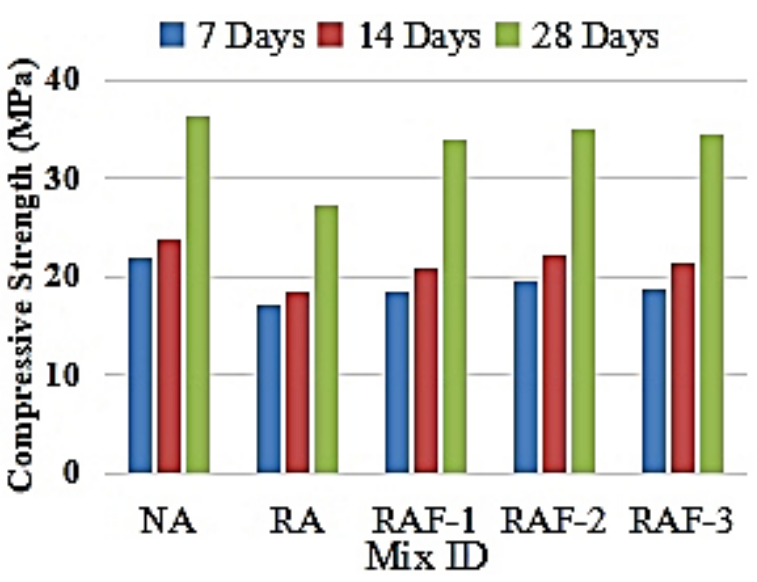

Fig. 3. Comp. strength results of mix-1

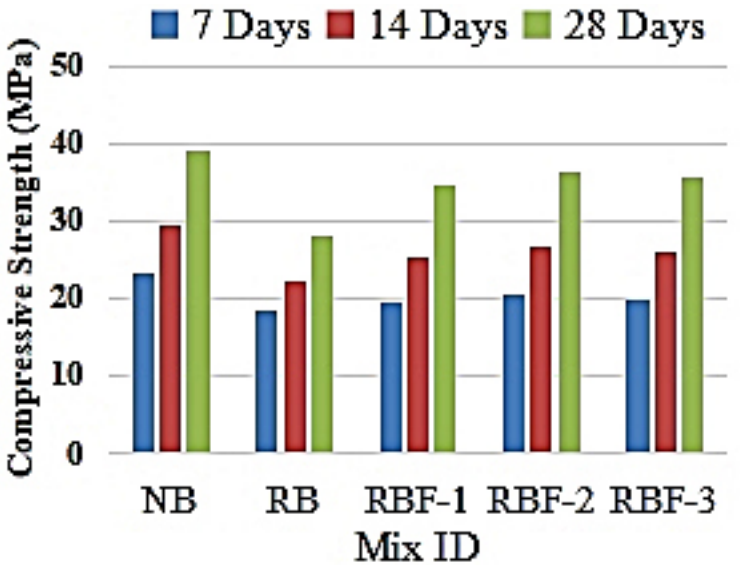

Fig. 4. Comp. strength results of mix-2 
$28.57 \% \& 32.55 \%$ lesser strength as compared to NB at $7,14 \& 28$ days, respectively, for mix-2. The results show that there is a reduction in the compressive strength of RBF-1, RBF-2 and RBF3 when contrasted with NB by $15.06 \%, 10.54 \%$ $\& 12.77 \%$ and $11.64 \%, 7.25 \% \& 9.42 \%$ at 14 and 28 days, respectively. A similar trend of results was observed for mix-2. The experimental results of mix-1 \& mix-2 observed that the difference in compressive strength of RAF-2, RBF-2 with NA $\&$ NB is $4.04 \%$ and $7.25 \%$, respectively. Thus, it is viable to prepare RAC mixes with SF $0.5 \%$ per $\mathrm{m}^{3}$. Other researchers' tests have also shown a decrease in the compressive strength values of recycled concretes. Sagoe-Crentsil et al. demonstrated that the resistance values of concrete with a 23 percent additive of recycled aggregate were $5 \%$ lower than those of natural aggregate concrete [27]. Gomez-Soberón, on the other hand, assumed an $11 \%$ decrease in the compressive strength between the samples made of $100 \%$ recycled aggregate and concretes made of natural aggregate. However, when the natural aggregate exchange reached $30 \%$ the compressive strength decreased by $5 \%$ [28]. The optimum combination found through experiment was $100 \%$ recycled aggregate replacement with the addition of $0.5 \%$ steel fibre in RAC, similar to Senaratne et al. [29].

\section{Stage 2: Direct cost comparison and cost benefit analysis}

Firstly, to determine the costs and benefits of delivering C\&D waste to the sites for waste disposal or recycling, the amount of C\&D waste could settle in Nanded, Maharashtra, India (latitude 19.1114 North, longitude 77.2945 East) for each year must be analysed. The first question was: "Does the crushing plant accept C\&D debris if the Local Municipal Authority charges a dumping fee?" "Yes, they will accept C\&D waste if they have no dumping charge." All the crushing plants surveyed have replied. Five of the six crushing plants have also found that the delivered C\&D waste is always sorted out and free from containments. Another advantage is savings of INR 1290/- per cubic metre of concrete, leading to a total of INR 4,70,850/- annually. Other environmental advantages found included reducing air pollution, gas emission, energy consumption and noise pollution by saving landfill space. The operating costs for a plant, equipment and work were included in the Cost-Benefit Analysis (CBA). The next question asked was: "What costs does the plant have, and are other RCA costs involved?" The following question asked. The second part of the question was formulated so that all costs included as the recycling facilities could differ. The fuel used for installations and machinery is an essential factor in RCA production, accounting for $8 \%$ of total operating costs. For all facilities, the average fuel consumption was INR 1,79,371/- per annum per cubic metre of concrete.

CBA is a technique that contrasts various thoughts or alternatives and a financial worth utilizing both direct/backhanded expenses and benefits. The cost benefit investigation contrasts the task costs and a INR sum for the entirety of the undertakings benefits [30]. On the other hand, it clarified that elective techniques, such as cost viability examination, generally dissect every result in common units, instead of appointing everything a financial worth. The CBA method is dependent upon suspicions and carefulness while putting financial figures on intangible things. In any case, it is pivotal that these things are incorporated to increase a genuine sign of the full benefits that were tried [31]. Along these lines, this investigation assessed the theoretical and indirect benefits to decide if joining RA with SF is financially feasible. In order to carry out an accurate analysis, the weight proportions of concrete, which were utilised in experimental work, have to be converted into volume proportions presented in Tables 6 and 7 [32]. Tables $7 \& 8$ demonstrated conversion of weight mix proportions of M25 \& M-30 grade concrete to volume mix proportions as $[1: 2.68: 2.20: 0.53] \&$ [1:2.42:1.93:0.48] respectively. This calculated volume mix proportion was used in the calculation of the cost of various concrete of NAC \& RAC. The cost of each concrete was evaluated using the State Schedule of Rates, 2020-21 [18] for concrete production per cubic metre.

Before deciding the cost of RCA, it is advisable to know the various processes involved in the crushing process of coarse aggregate. It was presented in the form of Figure 5 [29]. The data collection method was adopted by interviewing managers of major crushing plants around Nanded, Maharashtra, India (latitude 19.1114 North, longitude 77.2945 East) producing NCA. The data collected from Crushing Plant designated as [CP1-CP6] regarding various heads of expenses incurred for NCA production from stone or rock obtained from a quarry. It was listed in Table 9. 
Table 7. Corrections required for the nominal mix of M25

\begin{tabular}{|c|c|c|c|c|c|}
\hline Item & \multicolumn{2}{|c|}{$\begin{array}{l}\text { Cement } \\
\text { (OPC) }\end{array}$} & $\begin{array}{c}\text { FA (Sand) } \\
{[a]}\end{array}$ & $\begin{array}{c}\mathrm{CA}(20 \mathrm{~mm}) \\
{[\mathrm{b}]}\end{array}$ & $\begin{array}{l}\text { T.A. } \\
{[a+b]}\end{array}$ \\
\hline M25 mix & \multicolumn{2}{|c|}{1} & 1.77 & 2.65 & 4.42 \\
\hline Original volume calculations & $50 \mathrm{~kg}$ & 35 lit.(1) & $1.77 \times 35=61.95$ lit. & $2.65 \times 35=92.75$ lit. & \\
\hline Gravel in FA correction (18\%) & $50 \mathrm{~kg}$ & 35 lit.(1) & $\begin{array}{l}61.95 \times 100 / 82 \\
=75.54(2.15)\end{array}$ & $\begin{array}{c}92.75 \text { lit. } \\
(2.65)\end{array}$ & 4.80 \\
\hline $\begin{array}{l}\text { Bulk-age of damp FA correction } \\
(20 \%)\end{array}$ & $50 \mathrm{~kg}$ & 35 lit.(1) & $\begin{array}{c}75.54 \times 1.20 \\
=90.65(2.59) \text { damp }\end{array}$ & $\begin{array}{c}92.75 \text { lit. } \\
(2.65)\end{array}$ & 5.24 \\
\hline $\begin{array}{l}\text { F.M. correction a) If FA is too } \\
\text { coarse: + } 5 \text { FA \& - } 5 \mathrm{CA} \\
\text { b) If still no cohesion: } \\
+5 \mathrm{FA} \&-5 \mathrm{CA}\end{array}$ & $50 \mathrm{~kg}$ & 35 lit.(1) & $\begin{array}{c}90.65+5=95.65 \\
(2.73) \text { Damp } \\
95.65+5=100.65 \\
(2.88) \text { Damp }\end{array}$ & $\begin{aligned} & 92.75-5 \\
= & 87.75(2.51) \\
& 87.75-5 \\
= & 82.75(2.36)\end{aligned}$ & 5.24 \\
\hline $\begin{array}{l}\text { Silt in FA correction Penalty is } \\
(2 \%)\end{array}$ & $50 \mathrm{~kg}$ & 35 lit.(1) & $\begin{array}{r}100.65 \times 0.98 \\
=98.63(2.82)\end{array}$ & $\begin{aligned} & 82.75 \times 0.98 \\
= & 81.10(2.32)\end{aligned}$ & 5.14 \\
\hline $\begin{array}{l}\text { Flaky CA correction } \\
\text { (5\% Penalty) }\end{array}$ & $50 \mathrm{~kg}$ & 35 lit.(1) & $\begin{array}{r}98.63 \times 0.95 \\
=93.69(2.68)\end{array}$ & $\begin{array}{c}81.10 \times 0.95= \\
77.04(2.20)\end{array}$ & 4.88 \\
\hline Final mix & & & (2.68) & $(2.20)$ & 4.88 \\
\hline
\end{tabular}

Table 8. Corrections required for the nominal mix of M30

\begin{tabular}{|c|c|c|c|c|c|}
\hline Item & \multicolumn{2}{|c|}{$\begin{array}{l}\text { Cement } \\
\text { (OPC) }\end{array}$} & $\begin{array}{c}\text { FA (Sand) } \\
{[a]}\end{array}$ & $\begin{array}{c}\mathrm{CA}(20 \mathrm{~mm}) \\
{[\mathrm{b}]}\end{array}$ & $\begin{array}{l}\text { T.A. } \\
{[a+b]}\end{array}$ \\
\hline M30 mix & \multicolumn{2}{|c|}{1} & 1.58 & 2.36 & 3.94 \\
\hline Original volume calculations & $50 \mathrm{~kg}$ & 35 lit.(1) & $1.58 \times 35=55.3$ lit. & $2.36 \times 35=82.6$ lit. & \\
\hline Gravel in FA correction (18\%) & $50 \mathrm{~kg}$ & 35 lit.(1) & $\begin{aligned} & 55.3 \times 100 / 82 \\
= & 67.44(1.93)\end{aligned}$ & $\begin{array}{l}82.6 \text { lit. } \\
(2.36)\end{array}$ & 4.29 \\
\hline $\begin{array}{l}\text { Bulk-age of damp FA correction } \\
(20 \%)\end{array}$ & $50 \mathrm{~kg}$ & 35 lit.(1) & $\begin{array}{c}67.44 \times 1.20 \\
=80.93(2.31) \text { damp }\end{array}$ & $\begin{array}{l}82.6 \text { lit. } \\
(2.36)\end{array}$ & 4.67 \\
\hline $\begin{array}{l}\text { F.M. correction a) If FA is too } \\
\text { coarse : + } 5 \text { FA \& - } 5 \mathrm{CA} \\
\text { b) If still no cohesion: } \\
+5 \mathrm{FA} \mathrm{\&} \mathrm{-} 5 \mathrm{CA}\end{array}$ & $50 \mathrm{~kg}$ & 35 lit.(1) & $\begin{array}{c}80.93+5=85.93 \\
\quad(2.46) \text { Damp } \\
85.93+5=90.93 \\
\text { (2.60) Damp }\end{array}$ & $\begin{array}{c}82.6-5=77.6 \\
(2.22) \\
77.6-5=72.6 \\
(2.07)\end{array}$ & 4.68 \\
\hline $\begin{array}{l}\text { Silt in FA correction Penalty is } \\
(2 \%)\end{array}$ & $50 \mathrm{~kg}$ & 35 lit.(1) & $\begin{array}{l}90.93 \times 0.98 \\
=89.11(2.55)\end{array}$ & $\begin{aligned} & 72.6 \times 0.98 \\
= & 71.15(2.03)\end{aligned}$ & 4.58 \\
\hline $\begin{array}{l}\text { Flaky CA correction } \\
\text { (5\% Penalty) }\end{array}$ & $50 \mathrm{~kg}$ & 35 lit.(1) & $\begin{aligned} & 89.11 \times 0.95 \\
= & 84.65(2.42)\end{aligned}$ & $\begin{aligned} & 71.15 \times 0.95 \\
= & 67.59(1.93)\end{aligned}$ & 4.35 \\
\hline Final mix & & & $(2.42)$ & (1.93) & 4.35 \\
\hline
\end{tabular}

Table 9. Interview Sample for collection of heads of expenses per cubic metre for production of NCA with a lead of $0.5 \mathrm{~km}$ for various crushing plants

\begin{tabular}{|c|c|c|c|c|}
\hline $\begin{array}{c}\text { Crushing } \\
\text { Plant }\end{array}$ & $\begin{array}{c}\text { Basic cost of stone } \\
\text { from quarry (\%) }\end{array}$ & $\begin{array}{c}\text { Transportation of stone to } \\
\text { crushing plant including } \\
\text { royalty charges (\%) }\end{array}$ & $\begin{array}{c}\text { Crushing cost including } \\
\text { electric and labour charges } \\
(\%)\end{array}$ & $\begin{array}{c}\text { Transportation cost of } \\
\text { stone to the required site } \\
(\%)\end{array}$ \\
\hline CP-1 & 24 & 29 & 25 & 22 \\
\hline CP-2 & 26 & 31 & 22 & 21 \\
\hline CP-3 & 21 & 34 & 29 & 16 \\
\hline CP-4 & 19 & 32 & 25 & 24 \\
\hline CP-5 & 26 & 33 & 20 & 21 \\
\hline CP-6 & 20 & 34 & 24 & 22 \\
\hline
\end{tabular}




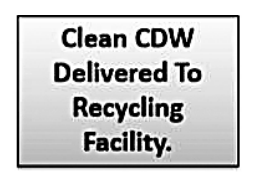

1

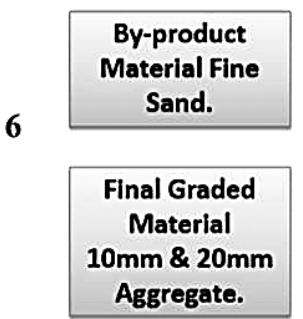

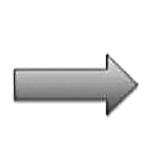

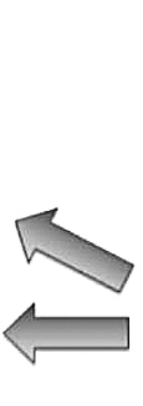

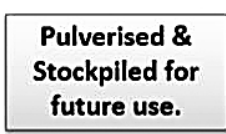

2

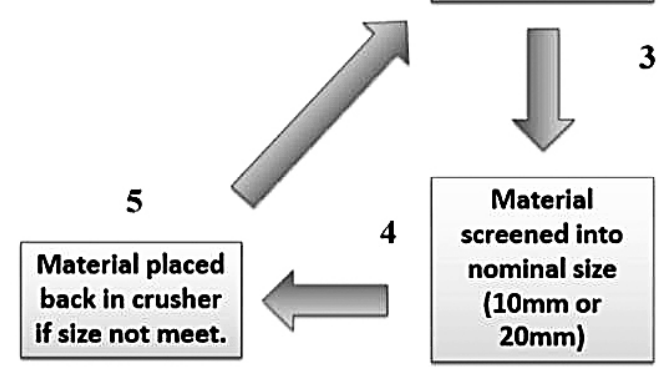

Fig. 5. Aggregate Recycling process

In Table 9, CP-1, CP-2, CP-3 belonging to Sharda Construction \& Private Limited, Nanded indicated an essential cost of stone used to produce NCA as $24 \%, 26 \%$ and $21 \%$ with a lead of $0.5 \mathrm{~km}$. The said variation occurred due to the geographical location of every site. CP-4 is located in the close vicinity of rock used for the production of NCA, compared to other plants. The above information found that the essential cost of metal or stone from a quarry is 19 to $26 \%$ of the total price of NCA per cubic metre. In terms of the availability of rock for NCA production, CP-5 is located away from the feedstock, in comparison with CP-6. CP-3 and CP-6 accepted only clean concrete washout material. Even when waste was dumped into landfills, it was sorted, and there was a greater tipping fee than in other crushing plants. Consumption of electricity for the operation of crushing plants, periodic repair of equipment, vehicle expenses to load and unload stone material into the hopper or jaw crusher were considered as a parameter for evaluation expenses head for production of NCA. Fuel, loading, and unload crushed aggregate and tipping fees were decided as the costs incurred to transport aggregate for a lead of $0.5 \mathrm{~km}$. Overhead has been determined as the last factor in maintenance costs. Fixed overhead corresponds to fixed prices with no change in daily activities, including insurance, rent, expenses for office, depreciation, etc. The average cost was INR 300/- per cubic metre of concrete for all facilities. The operating capital added to the INR $1,09,500 /-$ amount using $5 \%$ of the total cost per cubic metre.

It was concluded that the average cost of RCA is about $24.5 \%$ lesser than that of NCA per cubic metre as it obtained from free refused or discarded concrete debris. Considering this fact,

Table 10. Cost of one cubic metre of NAC, RAC and RAC with SF (excluding GST)

\begin{tabular}{|c|c|c|c|c|c|c|c|c|}
\hline \multirow{2}{*}{$\begin{array}{l}\text { Mix } \\
\text { ID }\end{array}$} & \multirow{2}{*}{$\begin{array}{l}\text { OPC } \\
\text { (Rs.) }\end{array}$} & \multirow{2}{*}{$\begin{array}{l}\text { Water } \\
\text { (Rs.) }\end{array}$} & \multirow{2}{*}{$\begin{array}{l}\text { Sand } \\
\text { (Rs.) }\end{array}$} & \multirow{2}{*}{$\begin{array}{l}\text { NCA } \\
\text { (Rs.) }\end{array}$} & \multicolumn{2}{|c|}{ RCA (Rs.) } & \multirow{2}{*}{$\begin{array}{c}\text { SF } \\
\text { (Rs.) }\end{array}$} & \multirow{2}{*}{$\begin{array}{c}\text { Total cost per cubic } \\
\text { metre (Rs.) }\end{array}$} \\
\hline & & & & & $20 \mathrm{~mm}$ & $10 \mathrm{~mm}$ & & \\
\hline \multicolumn{9}{|c|}{$1: 2.68: 2.20: 0.53$} \\
\hline NA & 275 & 3 & 4221 & 1980 & 0 & 0 & 0 & 6479 \\
\hline RA & 275 & 3 & 4221 & 0 & 896 & 598 & 0 & 5993 \\
\hline RAF-1 & 275 & 3 & 4221 & 0 & 896 & 598 & 548 & 6541 \\
\hline RAF-2 & 275 & 3 & 4221 & 0 & 896 & 598 & 1097 & 7090 \\
\hline RAF-3 & 275 & 3 & 4221 & 0 & 896 & 598 & 1646 & 7639 \\
\hline \multicolumn{9}{|c|}{$1: 2.42: 1.93: 0.48$} \\
\hline NB & 275 & 2.75 & 3811 & 1737 & 0 & 0 & 0 & 5825.75 \\
\hline RB & 275 & 2.75 & 3811 & 0 & 787 & 525 & 0 & 5400.75 \\
\hline RBF-1 & 275 & 2.75 & 3811 & 0 & 787 & 525 & 552 & 5952.75 \\
\hline RBF-2 & 275 & 2.75 & 3811 & 0 & 787 & 525 & 1104 & 6504.75 \\
\hline RBF-3 & 275 & 2.75 & 3811 & 0 & 787 & 525 & 1656 & 7056.75 \\
\hline
\end{tabular}


it was decided to take cost of RCA $24.5 \%$ less for evaluation of cost per cubic metre of NAC \& RAC Concrete. Table 10 represents the cost of producing one cubic metre concrete quantity of NAC, RAC and RAC with SF (excluding Goods \& Services Tax of Government of India) of M25 \& M30 grade using SSR,2020-21[18]. The above results showed that the cost difference between NA and RA for M25 grade concrete is $7.79 \%$, whereas it is $7.58 \%$ for concrete NB \& RB of M30 grade. Table 6 and 10 indicated that the compressive strength of RA \& RB is on the lower side when contrasted with NA \& NB, respectively. However, RAF-1 \& RBF-1 indicated comparable compressive strength for M25 \& M30 concrete grade and at the same time cost difference between NA \& NB with RAF-1 \& RBF-1 is $0.9523 \%$ and $2.14 \%$. The cost difference between RAF-2 and RBF-2 with NA \& NB was $9 \%$ and $11 \%$, respectively. At the same time, the cost difference between RAF-3 and RBF-3 with NA \& NB was $16.43 \%$ and $19.09 \%$, respectively. Recycling facilities rely heavily on contracts to produce RAC for concrete production. Awareness and promotion of RA at the policy level would solve the issue in full conformity with Senaratne et al. [29]. Quantifying these benefits was challenging, and the percentages used based on an extensive survey for a similar study in Queensland were close in conformity for calculation of cost in the present study [33]. The second part of CBA evaluated all plant and equipment needed to produce RAC, similar to the findings [34].

\section{CONCLUSIONS}

The obtained results pertaining to the compressive strength outcomes indicate that RAC with SF $0.25 \%$ per $\mathrm{m}^{3}$ gives a monetarily feasible solution from cost and benefit. The investigation uncovered in the paper is scientifically significant on account of introducing another fundamental construction material, which has noteworthy reasonable and cost benefits. The main benefits came from the fact that waste material was brought to the recycling facilities instead of being dumped into a landfill, as it usually would be. It is not only an economically viable material but also a sustainable material by reducing substantial landfill waste. This assessment offers recommendations for all social affairs stressed in reused aggregate concrete, for instance, producers, clients and originators, to propel this new material. The exploration revealed in the paper is scientifically significant because of the presentation of another primary construction material, which has impressive manageable and cost benefits. This examination offers a brainstorming thought to all manufacturers, customers and originators to advance this new material.

\section{Acknowledgements}

The authors would like to acknowledge Sharda Construction \& Private Limited, Nanded [CP1, CP-2 \& CP-3], Vikas Agrawal Stone Crusher, Nanded [CP-4], Jalaram Stone Crusher, Nanded [CP-5] \& Manoj Stone Crusher, Nanded [CP-6] for providing required information. It was helpful to decide the approximate cost of RCA based on the expenses incurred in NCA production.

\section{REFERENCES}

1. Behera M., Bhattacharyya S.K., Minocha A.K., Deoliya R., Maiti, S. Recycled aggregate from C \& D waste \& its use in concrete - A breakthrough towards sustainability in the construction sector: A review. Construction and Building Materials. 2014;68:501-516. DOI: 10.1016/j.conbuildmat.2014.07.003 2014

2. Kumatha R., Vijai K. Strength of Concrete Incorporating Aggregates Recycled from Demolition Waste. Asian Research Publishing Network Journal of Engineering and Applied Sciences. 2010;5:64-71.

3. Hashempour, H., Heidari H., Jounaghani M.S. The Efficiency of Hybrid BNN-DWT for predicting the Construction and Demolition Waste Concrete Strength. International Journal of Engineering, Transactions: B Applications. 2020;33:1544-1552. DOI:10.5829/IJE.2020.33.08B.12

4. Rao A., Jha K.N., Misra S. Use of aggregates from recycled construction and demolition waste in concrete. Resource Conservation Recycling. 2006;50(1):71-81. DOI:10.1016/j.resconrec.2006.05.010

5. Tam V., Economic comparison of concrete recycling: a case study approach. Resources, Conservation and Recycling. 2007;62:821-828. DOI: 10.1016/j.resconrec.2007.12.001

6. Hansen T.C., Narud H. Recycled Concrete and Fly ash makes Calcium Silicate Bricks Cement and Concrete Research. 1983;13:507-510. DOI:10.1016/0008-8846(83)90009-1

7. Bairagi, N.K., Ravande, K., Pareek, V.K. Behaviour of concrete with different proportions of natural and recycled aggregates. Resources, Con- 
servation and Recycling. 1993;9(1-2):109-126. DOI:10.1016/0921-3449(93)90036-F

8. Padmini A.K., Ramamurthy K., Mathews M.S. Influence of parent concrete on the properties of recycled aggregate concrete. Construction and Building Materials. 2009;23(2): 829-836. DOI:10.1016/j. conbuildmat.2008.03.006

9. Rao M.C., Bhattacharyya S.K., Barai S.V. Influence of field recycled coarse aggregate on properties of concrete. Materials and Structures. 2011;44(1):205220. DOI:10.1617/s11527-010-9620-X

10. Lahus O., Lillestol B., Hauck C. Use of Recycled Aggregate in Normal Concrete in Norway. Norwegian Building Research Institute. 2000;1-6. https:// www.irbnet.de/daten/iconda/CIB4276.pdf

11. Banthia N., Gupta P., Yan C., Morgan D.R. How tough is Fibre Reinforced Shotcrete? Part1, Beam Tests. Journal of Concrete International. 1999;59-62.

12. Akinkurolere O.O. Experimental Investigation on the Influence of Steel Fiber on the Compressive and Tensile Strength of Recycled Aggregate Concrete', Medwell Journals. 2010;264-268. DOI: 10.3923/ jeasci.2010.264.268

13. Xiao J., Li J., Zhang C. Mechanical properties of recycled aggregate concrete under uniaxial loading. Cement and Concrete Research. 2005;35(6):11871194. DOI: 10.1016/j.cemconres.2004.09.020

14. Heeralal M., Ratish Kumar P., Rao Y.V. Flexural Fatigue Characteristics of Steel Fibre Reinforced Recycled Aggregate Concrete (SFRRAC). FACTA Universities, Architecture and Civil Engineering. 2009;7(1):19-33. DOI:10.2298/FUACE0901019H

15. Prathipati T., Rao C.B.K., Dakshina Murthy N.R. Mechanical Behaviour of Hybrid Fiber Reinforced High Strength Concrete with graded fibres. International Journal of Engg., Transactions: B Applications.2020;33:1465-1471. DOI: 10.5829/IJE.2020.33.08B.04

16. Tam V., Mirza O., Senaratne S., Kang W., Kotrayothar D. Recycled Aggregate Concrete: Strength Development and Future Perspectives on Steel Fibres and Cost Benefit Analysis. Challenges. Innovation and Collaboration in Construction \& Engineering. Bangkok, Thailand; 2013.

17. Tam V., Mirza O., Senaratne S., Kang W. Sustainable structural material combining recycled aggregate and steel fibres. 3rd World Construction SymposiumColombo, Sri Lanka 2014.

18. Public Works Department, Government of Maharashtra. State Schedule of Rates; 2020-21.

19. Creswell J. Research Design: Qualitative, Quantitative, and Mixed Method Approaches (Fifth Edition). SAGE Publishing; 2003.
20. BIS-10262. Guidelines for concrete mix design proportioning (CED 2: Cement and Concrete). Bureau of Indian Standards; 2009.

21. BIS-456.Indian Standard Plain and Reinforced Concrete Code of Practice. Bureau of Indian Standards; 2000.

22. BIS-383.Coarse and Fine Aggregate for ConcreteSpecification (Third Revision). Bureau of Indian Standards; 2016.

23. BIS-8112. Specifications for 43 Grade Ordinary Portland Cement. Bureau of Indian Standards; 1989.

24. A820-01.Standard Specifications for Steel Fibers for Fiber Reinforced Concrete. ASTM International; 2013.

25. Etxeberria M., Marí A.R., Vázquez E. Recycled aggregate concrete as structural material. Materials and Structures. 2007;40(5):529-541. DOI:10.1617/ s11527-006-9161-5

26. Salem R.M., Burdette E.G. Role of Chemical and Mineral Admixture on Physical Properties and Frost-Resistance of Recycled Aggregate Concrete. ACI Materials Journal. 1998;95(5):558-563. https://rid.trb.org/view/542151

27. Sagoe-Crentsil K.K., Brown T., Taylor A.H. Performance of Concrete Made with Commercially Produced Coarse Recycled Concrete Aggregate. Cement Concrete Research. 2001;31:707-12. DOI:1016/S0008-8846(00)00476-2

28. Gómez-Soberón M.J. Porosity of Recycled Concrete with Substitution of Recycled Concrete Aggregate: an experimental study. Cement Concrete Research. 2002;32:1301-11. DOI:10.1016/s00088846(02)00795-0

29. Senaratne S., Gerace D., Mirza O., Tam V.W.Y. The costs and benefits of combining recycled aggregate with steel fibres as a sustainable, structural material. Journal of Cleaner Production. 2015; 1-10. DOI:10.1016/j.jclepro.2015.10.041

30. Cellini, S.R., Kee, J.E., Cost-effectiveness and cost benefit analysis. John Wiley and Sons; 2010.

31. Johannesson $M$. The relationship between costeffectiveness analysis and cost - benefit analysis. Social Science \& Medicine. 1995;41(4):483-489. DOI: 10.1016/0277-9536(94)00353-u

32. Remedios A.P. Concrete Mix Design. Himalaya Publishing House; 2008.

33. Tam V. Economic comparison of concrete recycling: a case study approach. Resources Conservation \& Recycling. 2008;62:821-828.

34. AASB. Property, Plant and Equipment. Commonwealth of Australia. 600 Bourke Street, Melbourne, Victoria, Australia 2009. 